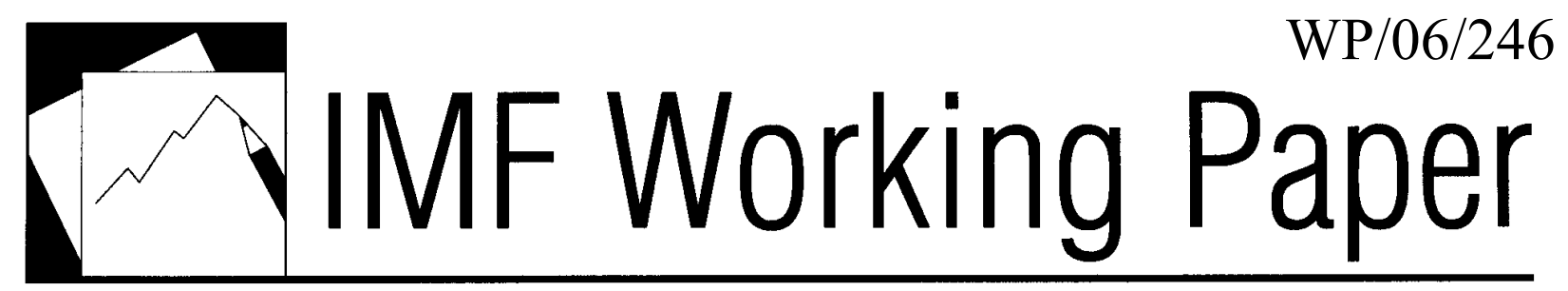

\title{
Monetary Transmission Mechanisms in Belarus
}

Balázs Horváth and Rodolfo Maino 



\title{
IMF Working Paper
}

\author{
Monetary and Financial Systems Department
}

\section{Monetary Transmission Mechanisms in Belarus}

Prepared by Balázs Horváth and Rodolfo Maino ${ }^{1}$

Authorized for distribution by Lorenzo Figliuoli and Peter Stella

November 2006

\begin{abstract}
This Working Paper should not be reported as representing the views of the IMF. The views expressed in this Working Paper are those of the author(s) and do not necessarily represent those of the IMF or IMF policy. Working Papers describe research in progress by the author(s) and are published to elicit comments and to further debate.

We explore monetary policy transmission by estimating VAR impulse response functions to illustrate the Belarusian economy's response to unexpected changes in policy and exogenous variables. We find a significant exchange rate pass-through to prices, and interest rate policy following, rather than leading, financial market developments. Our estimated monetary policy reaction function shows the central bank striking a balance between real exchange rate stability and containing inflation. We discuss dollarization, administrative interventions, and other features complicating monetary policy transmission, review specific constraints and vulnerabilities, and conclude with observations on possible measures that could raise the effectiveness of monetary policy in Belarus.
\end{abstract}

JEL Classification Numbers: C22, C32, E31, E51, E52

Keywords: Monetary policy, inflation, transmission mechanisms, dollarization.

Authors’ E-Mail Addresses: bhorvath@imf.org; rmaino@imf.org

\footnotetext{
${ }^{1}$ An earlier version of this paper was presented at the National Bank of the Republic of Belarus (NBRB) Conference on Monetary Policy Transmission Mechanism in Transition Economies in Minsk February 20-21, 2006, and at the State University of Belarus, May 22, 2006. The authors are grateful, without implication, to Reza Anglingkusumo, Veronica Bacalu, Ritu Basu, Lorenzo Figliuoli, Denis Krivorotov, Mikhail Pranovich, Peter Stella, Jerome Vandenbussche, and participants in the NBRB conference for their comments.
} 


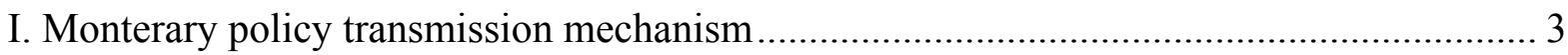

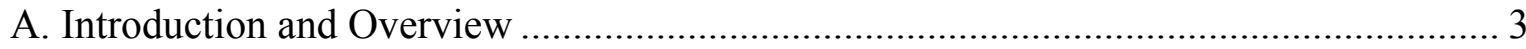

B. Specific Channels of Transmission ......................................................................... 4

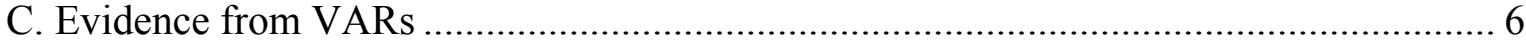

D. Dollarization, Balance Sheet Effects, and Financial Vulnerabilities .............................. 9

II. Constraints, Vulnerabilities, and the Road Ahead ....................................................... 14

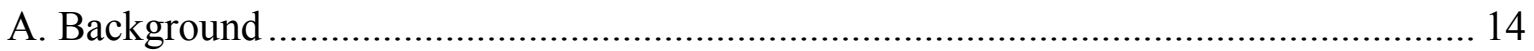

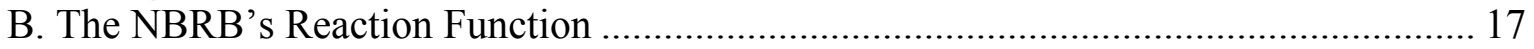

III. Steps Toward Enhancing Monetary Policy Effectiveness ............................................... 19

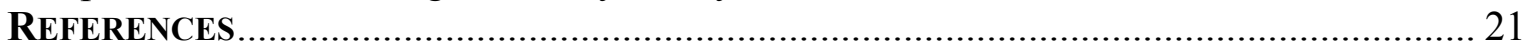

Tables

1. Granger Causality: NBRB Refinancing Rate vs. Interbank Interest Rates....................7

2. Reaction Functions (Based on GMM), 1996-2005 ……………...............................17

Figures

1. Response of Prices to One-Standard-Deviation Nominal Exchange Rate Change .......7

2. Response of Prices to Money One-Standard-Deviation Change ...................................8

3. Response of Output Gap to Money One-Standard-Deviation Change ...........................9

4. Financial Dollarization and Inflation in Belarus....................................................12

5. Financial Dollarization and the Real Exchange Rate in Belarus .................................13

6. Response of Dollarization to a One-Standard-Deviation Real Exchange Rate

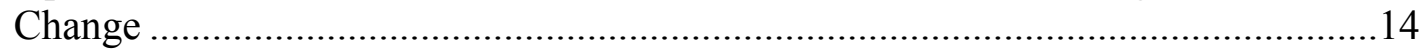

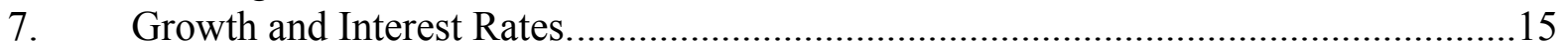

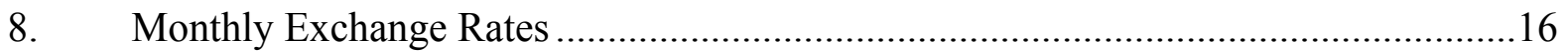

9. Changes in the Nominal Exchange Rate, 1996-2005 .................................................19

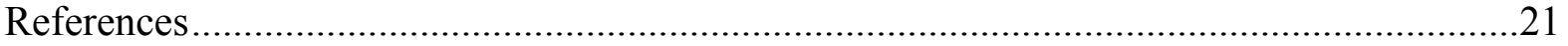




\section{Monetary Policy Transmission Mechanism}

\section{A. Introduction and Overview}

This paper aims to analyze the effects of monetary policy actions and exogenous shocks on inflation and output in Belarus, and on this basis, to explore how monetary policy effectiveness could be enhanced. During the past decade, the period under study, Belarus has first experienced high inflation and rapid exchange rate depreciation. Both have subsequently declined owing to policy improvements, notably the unification of exchange rates in 2001, and the successful use of the exchange rate as a nominal anchor by the National Bank of the Republic of Belarus (NBRB) in recent years. These, together with improvements in the conduct and implementation of monetary policy, as well as price controls, have contributed to decelerating inflation. However, the high level of dollarization, and the coexistence of several monetary policy targets - on inflation, the nominal exchange rate, directed credits, and interest rates - have complicated monetary policy implementation. The NBRB has faced constraints, notably administrative intervention in price formation that affected the price level, interest rate controls that limited the capacity to rely on the interest rate channel, and a shallow and underdeveloped capital market. On the positive side, it has benefited from rapidly expanding economic activity and benign external conditions.

The design and conduct of monetary policy critically depends on a proper assessment and understanding of the effects of policy changes and shocks on relevant macroeconomic variables and their timing. The analysis of different transmission channels helps describe their specific characteristics, such as their relative dominance, importance, and their speed of propagating policy effects (although, as noted by Loayza and Schmidt-Hebbel (2002), it is not always possible to empirically distinguish among the various channels). In this analysis, it is useful to discriminate (i) the transmission from instruments directly under the central bank's control to financial conditions; and (ii) the impact of financial conditions on firms' and households' spending decisions. The effectiveness of the various channels through which monetary policy is transmitted to prices, output, and the exchange rate depends on both of these segments. The transmission mechanism is also affected by the economy's financial structure - the sophistication of financial markets, the financial condition of the banking system, the degree of dollarization, balance sheet heterogeneity - and by the macroeconomic environment. A key aspect concerning the effectiveness of monetary policy transmission in Belarus is the extent of fiscal dominance and of government intervention in financial markets aimed at controlling the exchange rate, and the direction, size, and terms of bank lending.

The paper is organized as follows. Following an overview of monetary policy transmission channels with references to the relevant literature, it presents estimated impulse response functions showing the dynamic effects of unanticipated policy or exogenous shocks. The paper then discusses dollarization and other features of emerging and transition country economies that affect the transmission of monetary policy. We then review the constraints facing the NBRB, and empirically investigate the monetary policymaking process in Belarus by estimating a reaction function to gauge how the NBRB has reacted to changes in macroeconomic fundamentals. Finally, we elaborate on the potential implications of specific constraints and describe measures that could help improve monetary policy effectiveness. 


\section{B. Specific Channels of Transmission}

Several channels of transmission of monetary policy have been identified in modern financial systems. The most conventional mechanism is the interest rate channel, which alters the marginal cost of lending and borrowing, affecting economic agents' cash flow and time preferences for consumption, thus producing changes in investment, savings, and aggregate demand. Clearly, an interest rate cut reduces the marginal cost of borrowing, which boosts current spending, hence aggregate demand. In contrast, rising interest rates reduce cash-flow and spending, but raise savings. A key aspect is the extent to which a change in the central bank-controlled policy interest rate affects the term structure of interest rates (the yield curve) - especially short-term money market rates, and long-term rates. The propagation mechanism of monetary policy decisions along the yield curve depends on institutional aspects - notably the structure and organization of financial markets, with deeper financial markets allowing for more rapid and predictable propagation of effects - as well as on economic agents' reactions. The latter, in turn, hinges on their expectations, their balance sheet positions, the share of financial assets and liabilities carrying fixed and variable interest rates, and the relative importance of marginal and average interest rate effects. In Belarus, the coexistence of interest rate controls, dominant state-owned banks and shallow markets substantially weaken the interest rate transmission channel. Credit does not readily react to changes in interest rates, given that systemic state-owned banks have limited incentives to lend on the basis of commercial criteria, directed lending is widespread, and limits on interest rates are often binding.

The exchange rate channel describes the effect of the exchange rate on the domestic economy through both aggregate demand (net exports) and supply (domestic value of imports). Its effectiveness depends on the extent of exchange rate pass-through and on capital flows, factors that also substantially affect the available scope for a flexible exchange rate policy. The level of the pass-through to the local currency price of imported goods and services and, hence, to overall inflation depends on the import share, the magnitude of the devaluation and its timing, as well as structural characteristics of the economy. Generally speaking, the larger the import share and the magnitude of a devaluation, the larger the passthrough (but, among other factors, the level of competition in the economy also plays a role). Moreover, a devaluation during a recession could imply a smaller pass-through, given the slack in the utilization rate of factors of production. A relatively high degree of dollarization in Belarus is consistent with the existence of a significant pass-through effect from the exchange rate to prices.

When facing sizable capital flows, a central bank may find it difficult and costly to manage liquidity with banks having the option of drawing on external assets and foreign credit lines in response to interest rate differentials between domestic and foreign dollar assets. By the same token, attempts to expand credit in the domestic banking system during a downturn (when domestic interest rates are low) might face considerable obstacles since private agents and banks may redirect liquidity abroad in response to the shrinking interest premium relative to foreign assets.

The credit channel operates through nonprice credit rationing stemming from asymmetric information and/or directed credit. This channel is prominent when government intervention 
in the loan market is strong, interest rates are strictly regulated, or credit markets are shallow. In such contexts, economic activity does not closely depend on changes in the price of credit, so monetary policy tends to resort to directly controlling the availability of credit to influence aggregate demand. A monetary contraction - in the absence of offsetting supervisory forbearance - reduces the availability of banks' loanable resources and hence bank lending, thereby lowering output (primarily through lower investment).

The asset price channel reflects the impact of monetary policy on the prices of bonds, shares, real estate, and other domestic assets. It operates through changes in firms' market value and in household wealth. The former alters the relative price of new equipment, affecting investment spending, while the latter affects household consumption and the availability of collateral for borrowing.

Finally, the expectations channel is associated with economic agents' perception about intertemporal rates of substitution. In Belarus's case, the expectations channel associated with the exchange rate seems to have played an important role in lowering inflation owing to its strong signaling role in the economy, allowing it to act as a nominal anchor effectively.

All transmission channels are sensitive to dollarization, defined as the widespread domestic use of foreign currencies as a store of value and for transactional purposes. Dollarization affects balance sheet positions, financial sector technology, institutions, and expectations. It reduces the central bank's influence on monetary aggregates, distorts the link between domestic money and inflation, increases the vulnerability of the financial and enterprise sectors to changes in the exchange rate, and alters the timing and effects of monetary shocks. In economies characterized by high dollarization and shallow financial markets, the exchange rate channel is often most prominent.

The various transmission channels are interlinked. For instance, the expectation channel may depend on the exchange rate channel — and hence on the extent of dollarization-owing to the strong signaling role of the exchange rate. Moreover, the interest rate channel interacts with the credit channel by affecting the cost of borrowing, and with the exchange rate channel through interest rate parity. 


\section{Evidence from VARs}

\section{Theory}

To empirically assess the effects of monetary policy and other policy-related variables on output, exchange rate, and prices, we have estimated a five-variable Vector Autoregression (VAR) model to characterize monetary policy and study the impact of the exchange rate on inflation for the period 1995-2005. ${ }^{2}$ The VAR methodology - a dynamic system of equations in which the current level of each variable depends on past movements of that variable and all other variables involved in the system - places minimal restrictions on the description of how monetary shocks affect the economy. An unrestricted VAR is represented by

$y_{t}=A(L) y_{t}+u_{t}$

where $y_{t}$ is a vector including endogenous and exogenous variables (logarithm of real GDP, CPI, real exchange rate, interbank rates, monetary aggregates, and the U.S. Federal Funds rate), $\mathrm{A}(\mathrm{L})$ corresponds to the matrices of coefficients to be estimated (with lag lengths determined on the basis of Schwartz and AIC criteria), and $u_{t}$ is a vector of innovations that may be contemporaneously correlated but are uncorrelated with their own lagged values and with the right-hand side variables. ${ }^{3}$ Using the estimated VAR, we can also analyze short-term dynamics based on variance decompositions, Granger causality tests, and impulse response functions.

\section{Empirical investigation}

Empirical results indicate a rather strong exchange rate pass-through in Belarus. Relatively high dollarization and an effectively fixed nominal exchange rate vis-à-vis U.S. dollar in recent years have contributed to a significant estimated pass-through effect from the exchange rate to prices. Estimates from this VAR are described in Figures 1-3 where the dotted lines represent 90 percent confidence intervals. The vertical axis shows the deviation from the baseline level of the target variable in response to a change in the shock variable of one standard deviation, while the horizontal axis presents the number of months elapsed after the shock. Figure 1 shows a marked pass-through for Belarus. While the direct effect on the price level tapers off and loses statistical significance after five months, it implies a substantial cumulative impact on prices. This result, however, does not mean that allowing some exchange rate fluctuation would necessarily have strong repercussions, since monetary and fiscal policies could adjust to limit the pass-through.

\footnotetext{
2 The variables are money, inflation, output gap, refinancing rate, and the nominal exchange rate (parallel market exchange rates for the period December 1995-October 2001, official exchange rate thereafter).

${ }^{3}$ The estimation is conducted on monthly data from 1995 to 2005.
} 
Figure 1. Response of Prices to One-Standard-Deviation Nominal Exchange Rate Change

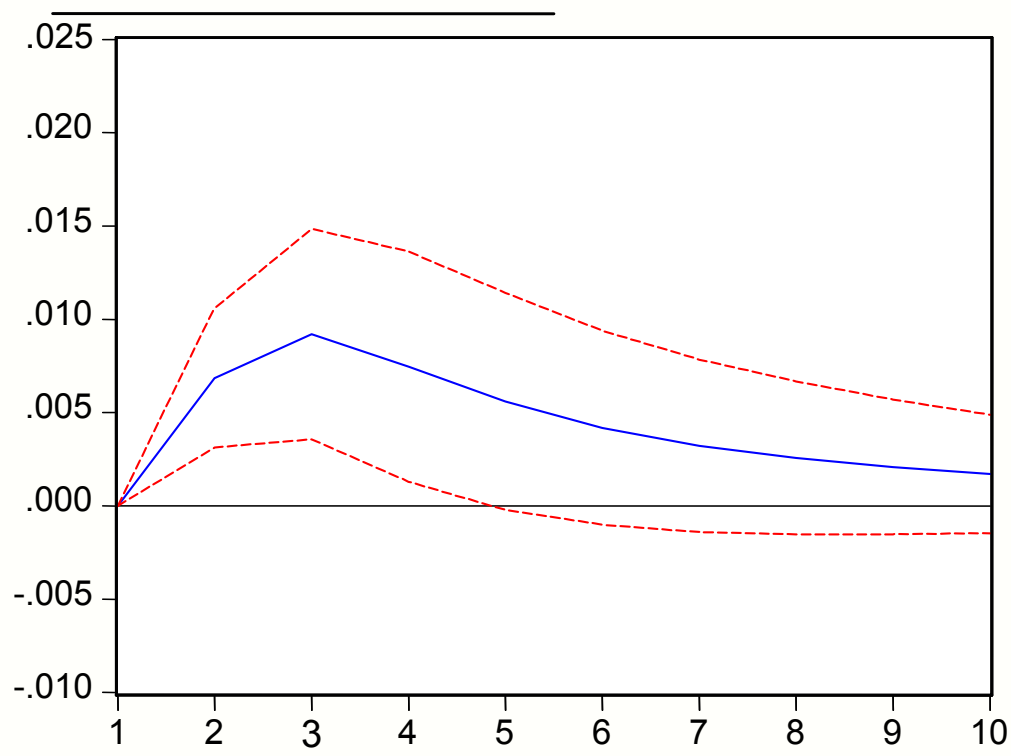

Source: Authors' calculations.

In another empirical inquiry, we find Granger causality running from the interbank rate to the refinancing rate, not - as expected - the other way around (Table 1). This statistical evidence suggests that the refinance rate follows changes in the interbank rate, in effect shadowing market trends. Thus, interest rate pass-through from policy to market interest rates appears to play a smaller role in Belarus than in more advanced transition economies. ${ }^{4}$ This result could reflect NBRB policy aiming to keep all interest rates roughly constant in real terms, adjusting the refinance rate only with a lag. Additional factors that could contribute to explaining this result include low monetization, underdeveloped financial markets, soft budget constraints for banks and enterprises, controlled interest rates, capital controls, as well as dollarization (see Section D).

Table 1. Granger Causality: NBRB Refinancing Rate versus Interbank Interest Rates Period: 1995:12-2005:10 (2 lags)

\begin{tabular}{lccc}
\hline \multicolumn{1}{c}{ Null Hypothesis } & $\begin{array}{c}\text { Number of } \\
\text { Observations }\end{array}$ & F-Statistic $^{1 /}$ & Probability \\
\hline Interbank rate does not Granger cause NBRB rate & 100 & 7.94 & 0.00 \\
NBRB rate does not Granger cause Interbank rate & & 1.68 & 0.19 \\
\hline
\end{tabular}

Source: Authors' calculations, ${ }^{1}$ Critical Value at 95 percent significance level: $\mathrm{F}_{0}=5.15$.

\footnotetext{
${ }^{4}$ See Égert and McDonald (2006) for a discussion on how the interest rate channel may be more effective in transition economies with deeper financial markets.
} 
The impact of money shocks on prices and output are rather different. Figure 2 highlights the persistence of a money shock on the price level: the impact is marked, statistically significant, and long-lived, confirming the important influence of money in determining inflation in Belarus.

Figure 2. Response of Prices to One-Standard-Deviation Change in Money

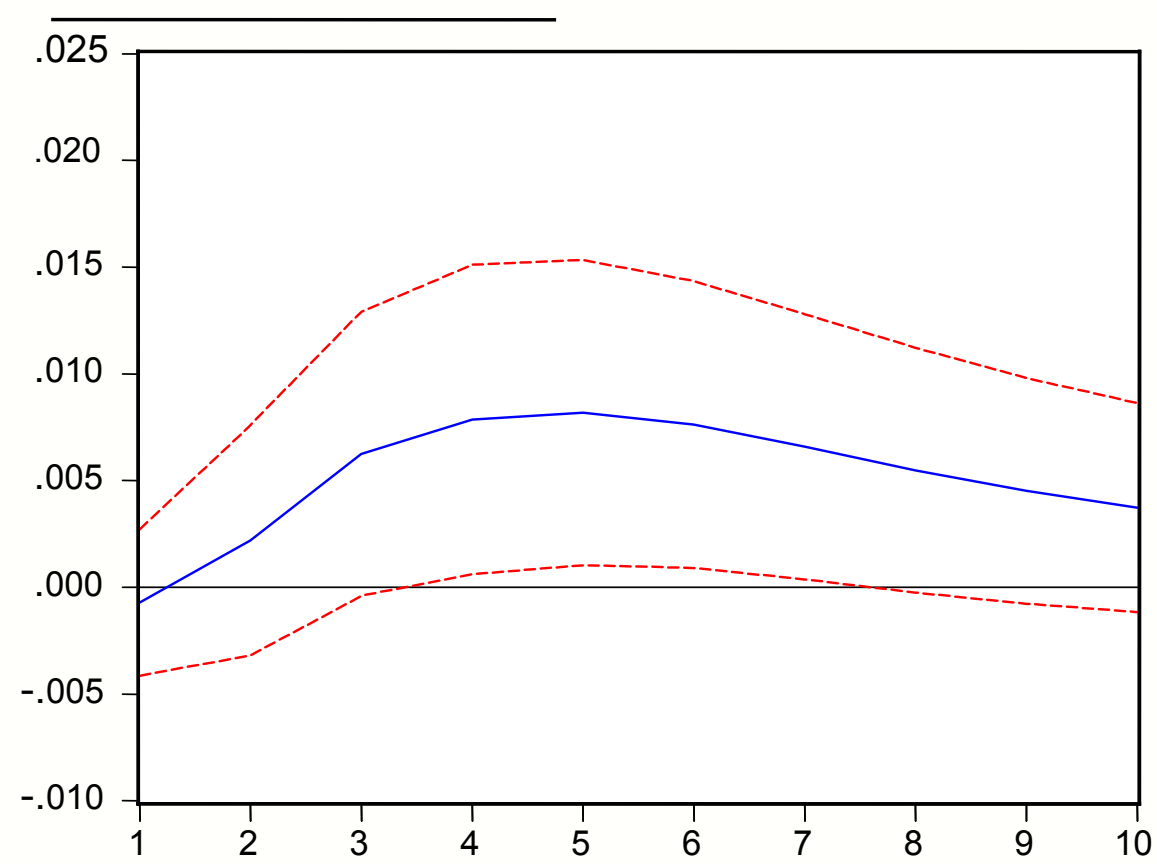

Source: Authors' calculations.

On the other hand, the effect of a monetary expansion on output is transitory. The response of output to a money shock (Figure 3 ) is statistically insignificant and short lived - a common finding for economies with low monetization levels and significant degrees of currency substitution. ${ }^{6}$ This result is also consistent with the view that the primary role of monetary policy should be to control inflation, and it should leave the task of maximizing output to other elements of the policy mix, notably to fiscal and structural policies.

\footnotetext{
5 This result is in line with those in Pelipas (2002).

${ }^{6}$ See, for example, Starr (2005) on the post-stabilization experiences of Russia, Kazakhstan, Ukraine, and Belarus.
} 
Figure 3. Response of Output to One-Standard-Deviation Change in Money

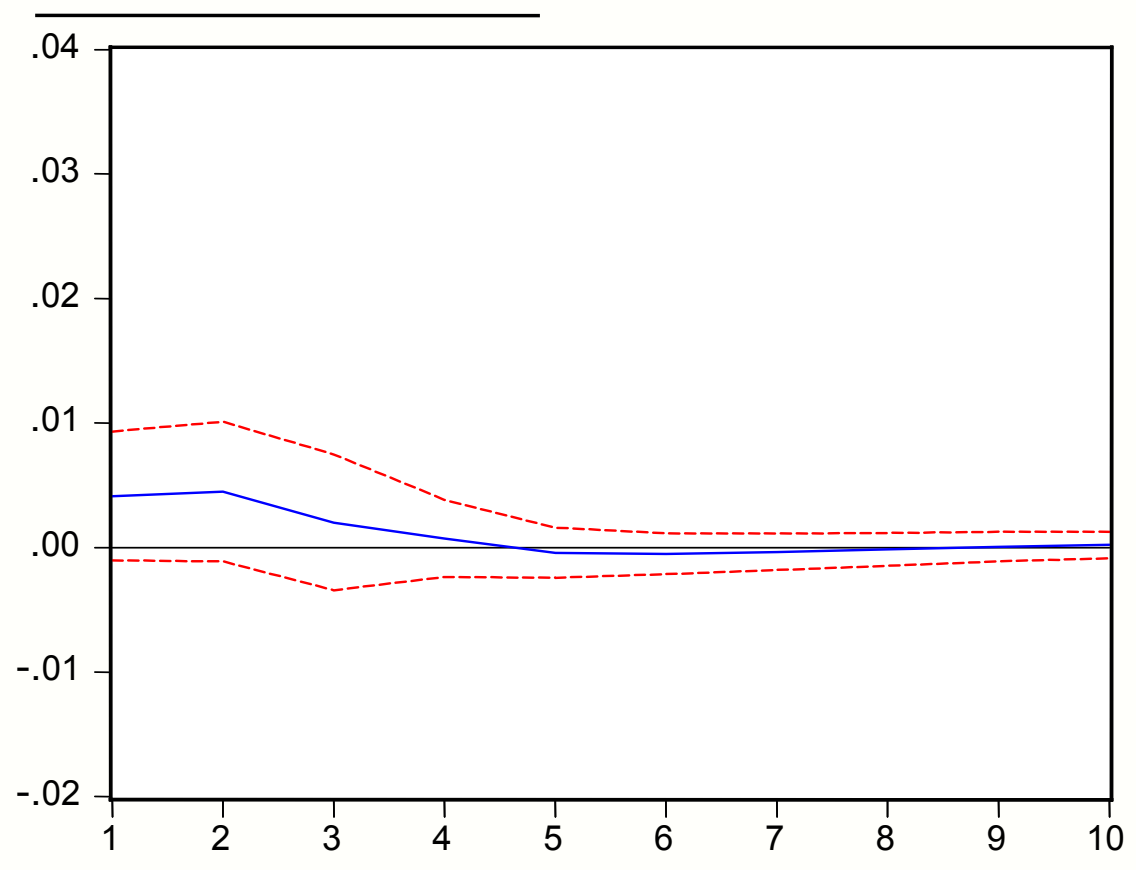

Source: Authors' calculations.

\section{Dollarization, Balance Sheet Effects, and Financial Vulnerabilities}

In heavily dollarized economies, the scope for an independent interest rate policy is limited. Monetary policy will have little independent control over domestic interest rates, since they are largely influenced by domestic dollar interest rates. These, in turn, are in close parity with the foreign dollar interest rate adjusted for domestic banks' commercial risk. A central bank in a highly dollarized economy can, nevertheless, implement monetary policy through local open-market operations, notably through regular auctions of treasury bills, repo operations and short-term remunerated dollar deposits at the central bank.

Dollarization can also weaken the impact of monetary expansion on bank lending. The transmission of monetary policy depends on the degree of substitutability between domestic currency and dollar assets as well as on the substitutability between domestic dollar assets and foreign dollar assets. Empirical evidence shows that in dollarized economies both forms of substitutability are quite strong. ${ }^{7}$ As a result, a large portion of the liquidity provided to boost domestic credit can leak in the form of capital outflows, resulting in very little increase in banking system credit to the private sector. On the other hand, if the government resorts to directing state-owned banks to allocate credit to selected domestic sectors, their profitability, and ultimately their capital position, might deteriorate.

\footnotetext{
${ }^{7}$ See Savastano (1996) for some evidence on Latin America.
} 
A close examination of the economy from a balance sheet perspective-with an emphasis on currency, maturity, and capital structure mismatches - is critical for monetary policy formulation in dollarized economies. The balance sheets of banks, firms, and households in many emerging and developing economies have liabilities mostly denominated in foreign currency, while assets are largely denominated in domestic currency (currency mismatch), exposing them to exchange rate risk. Maturity mismatches of liabilities and liquid assets expose balance sheets to roll-over (liquidity) risk, and to interest rate risk. Finally, capital structure mismatches stem from relying on debt rather than equity to finance investment, with important implications when income falls: dividends decline, whereas debt service remains unchanged, claiming a larger portion of income.

Given a combination of mismatches, shocks can trigger serious fluctuations in asset prices that affect the realized return on capital, net worth, and firms' investment decisions. The public sector can suffer from similar mismatches - especially if policies preclude substantial foreign investment inflows - owing to "original sin," affecting the country's external risk exposure. The existence of such mismatches in the economy can also significantly contribute to the volatility of expectations, with implications for monetary policy transmission.

Thus, monetary policy formulation should take into account private and public balance sheet vulnerabilities to exogenous shocks. For example, dollarization can significantly raise the domestic costs of unanticipated exchange rate movements. ${ }^{9}$ With large foreign exchangedenominated liabilities in banks' and firms' balance sheets, a sharp and unanticipated depreciation can induce a massive loss of net worth that can exacerbate real exchange rate movements, threaten the stability of the domestic financial system, and depress economic activity. ${ }^{10}$ Typically, firms in emerging markets lack the capacity to hedge because their financial markets are incomplete and foreign investors are willing to lend only in their own currency (Eichengreen and Hausmann, 1999). Unexpected appreciation can also cause serious problems for domestic agents - for example, banks - with significant net foreign exchange-denominated assets. The financial turmoil and currency crises experienced by Mexico in 1994 and Southeast Asia in 1997-98 have clearly shown the devastation from exchange rate shifts in the context of high liability dollarization and the associated financial fragility.

Consequently, countries with significant degrees of dollarization generally conduct monetary policy characterized by "fear of floating" or by crawling peg exchange rate regimes. ${ }^{11}$ Often, the monetary authority is able to manage liquidity in the money market to some extent

\footnotetext{
${ }^{8}$ Defined as a country's inability to borrow internationally in its domestic currency or for long maturities.

${ }^{9}$ See Calvo (1999), and Céspedes, Chang, and Velasco (2000).

${ }^{10}$ Unanticipated currency depreciations raise the cost of imports as well as exchange rate uncertainty. The resulting adverse effect on domestic output can outweigh the stimulating effect of depreciation on net exports.

${ }^{11}$ For instance, the Bolivian monetary authority has adopted a quasi-crawling exchange rate peg, with depreciation depending on the projected inflation differential. It sets discretionally the intervention rate and the rate of crawl in light of external shocks or daily changes in foreign exchange demand.
} 
through open-market operations, repos, reverse repos and liquidity credits, or to use international reserves as a systemic liquidity buffer. However, this still leaves a very limited scope for discretionary monetary policy, even if bolstered by the existence of capital controls, since neither the exchange rate, nor money supply is available as a free policy variable.

Dollarization, especially in the context of limited foreign exchange reserves, also leaves an economy more vulnerable to spill-over effects. If a devaluation severely damages corporate sector balance sheets, this can compromise the stability of the financial sector owing to a surge in nonperforming loans. Given the financial and business linkages among sectors, a problem that, at first, only affects one sector can rapidly spill over into other sectors and may cause a more widespread crisis. ${ }^{12}$ In particular, the need to repay or roll over foreign currency-denominated liabilities can result in a drawdown of foreign exchange reserves and can potentially trigger a payment crisis. This process can unfold quite rapidly if the capital account has been liberalized. Central banks in many dollarized economies therefore find it necessary to maintain high official foreign exchange reserves to reinforce their lender of last resort function, as well as to mitigate the risk of an external roll-over crisis or of a run on domestic dollar deposits. Alternatively, they attempt to maintain strict capital controls, an approach that eventually tends to fail, however, when tested by markets.

Activist monetary policy, emerging prudential risks, and dollarization reinforce each other. Under dollarization, the central bank seeks to moderate the fluctuations of the real exchange rate with a constrained set of instruments, while also maintaining the domestic currency's credibility. The limited effectiveness of monetary policy instruments and the less than precise ability to calibrate them may lead to the deployment of increasingly activist policies featuring direct interventions. While these policies can in principle be contractionary, in the Belarusian context they typically involve rapidly growing directed credits to selected sectors of the economy, as well as constraints on the enforcement of prudential standards. In these circumstances, however, even a limited shock can destabilize inflation and exchange rate expectations, or undermine trust in the domestic currency or in banks. These, in turn, can make banks' and firms' cash flow constraints binding, cause financial distress, and lead to further dollarization. Even withdrawals of foreign currency deposits could occur, resulting in pressure to provide adequate (dollar) liquidity to banks through repo operations or liquidity credits, and placing strains on foreign exchange reserves.

The level and volatility of financial dollarization in Belarus has decreased significantly from its 2001 level, reflecting disinflation and the stabilizing real exchange rate. From 70 percent of total deposits in the financial system in 2001, it fell on a volatile path to around 40 percent by 2005 . This path was similar to that of inflation, which has been relatively high compared to other countries in the region (Figure 4 is based on normalized data, with the y axis measuring standardized deviation from the mean). The real exchange rate oscillated sharply at the time of the Russian crisis in 1998, but subsequently appreciated and became more stable.

${ }^{12}$ Allen and others (2002) outline an analytical framework for understanding crises in emerging markets based on the aggregate balance sheet of a country's main sectors. 
Figure 4. Financial Dollarization and Inflation in Belarus

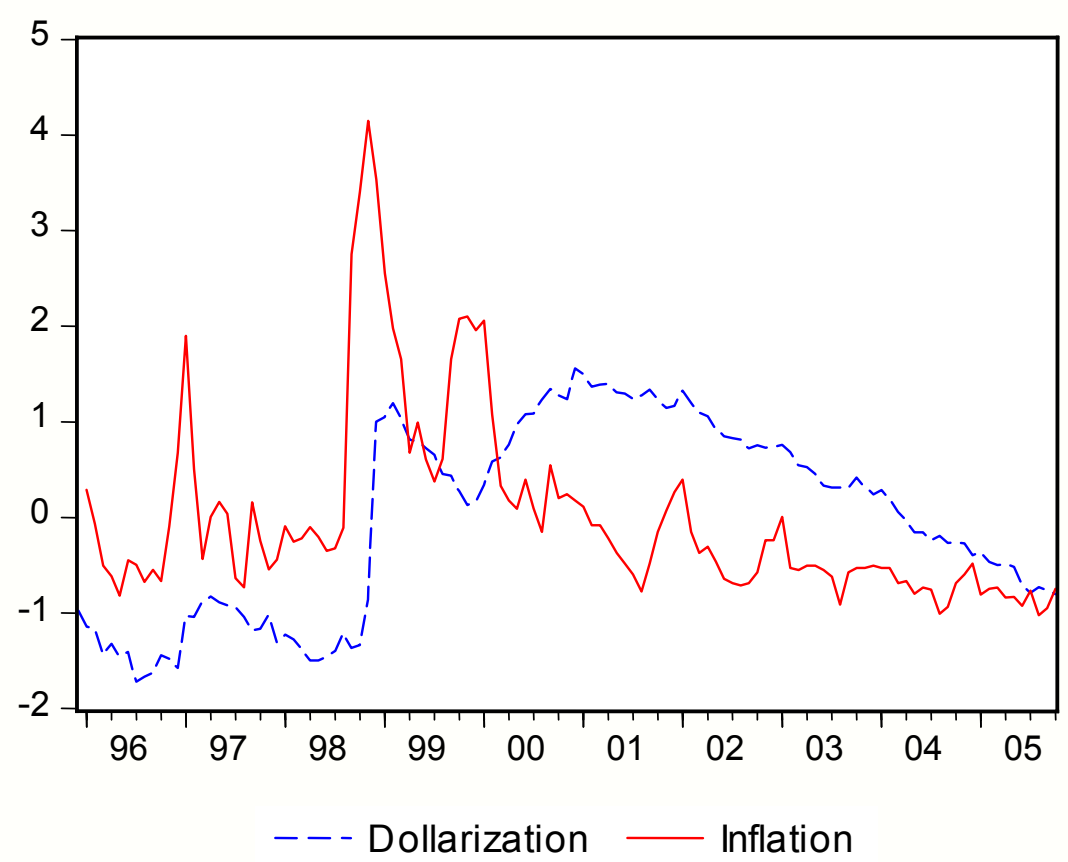

Source: Authors' calculations.

Consistent with standard portfolio theory, credible real exchange rate appreciation has also been closely associated with lower financial dollarization in Belarus (Figure 5, again based on normalized data). The decline in dollarization reflects the preference of domestic residents to move away from holdings and transactions in foreign currency when its purchasing power in terms of domestic consumption is no longer more stable than that of the domestic currency. According to this logic, expected real exchange rate volatility relative to inflation volatility should be a key driving force of dollarization (see also Ize and Yeyati, 2003). The experience of several dollarized economies in Latin America indeed showed real exchange rate volatility declining pari passu with inflation volatility. ${ }^{13}$

\footnotetext{
${ }^{13}$ Real exchange rate volatility tends to be anchored by a long-term purchasing power condition, while future inflation is uncertain despite current low levels of inflation.
} 
Figure 5. Financial Dollarization and the Real Exchange Rate in Belarus

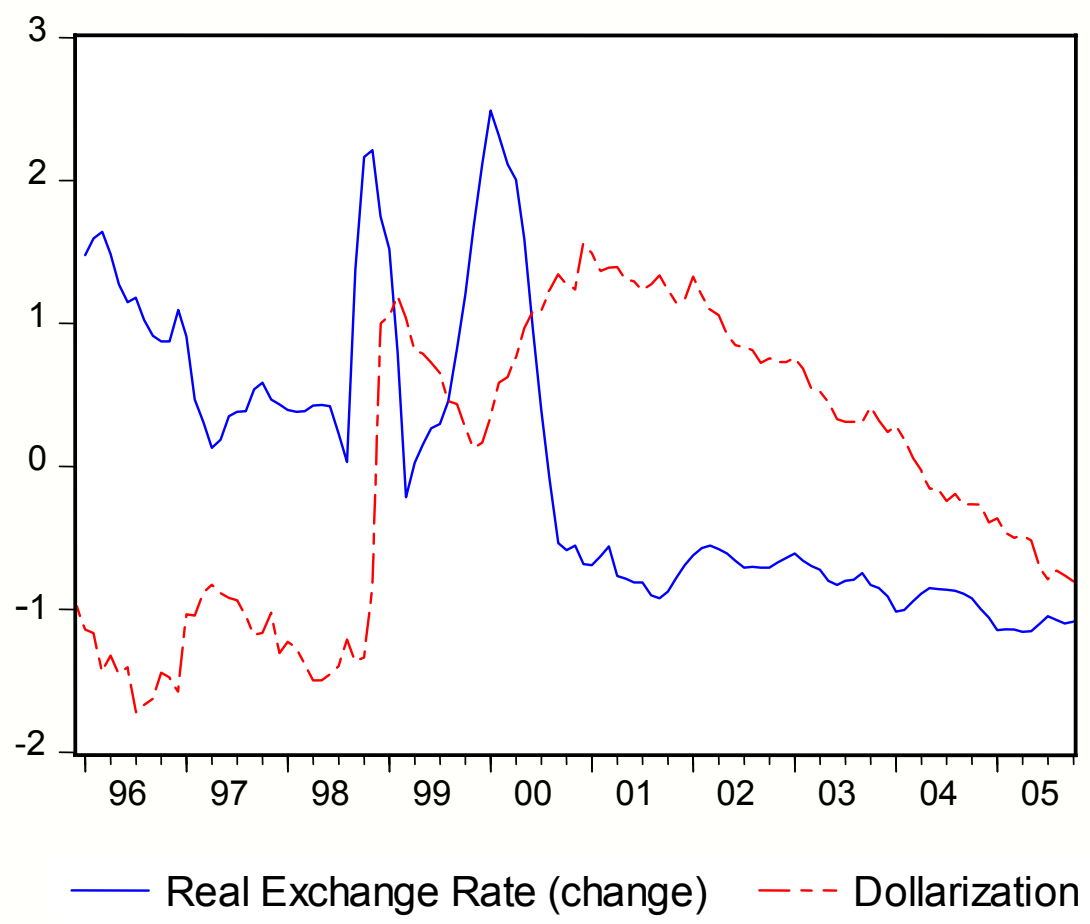

Source: Authors' calculations.

In contrast, for Belarus the econometric evidence supporting this relationship is weak. The most convincing test would directly relate financial dollarization to the volatility components of inflation and the exchange rate, but the analysis is complicated by the strong inertia in the dollarization process, seasonality effects, and other noise in high frequency data. Indeed, we do not find a statistically significant relationship between dollarization and volatilities for inflation and the exchange rate. The alternative of focusing on the short-term response of financial dollarization to changes in the real exchange rate (due to both the direct impact - a depreciation causes the local currency value of dollar assets to rise-and the indirect impact, acting through portfolio choices) does not work much better. In this setup, the impulse response function shows a non-transitory response that is, however, statistically insignificant at the 5 percent significance level (Figure 6). ${ }^{14}$

\footnotetext{
${ }^{14}$ We use a VAR model involving inflation, the domestic (policy) interest rate, the exchange rate, and dollarization. Similar results are obtained when testing for the response of dollarization to changes in inflation.
} 
Figure 6. Response of Dollarization to a One-Standard-Deviation Real Exchange Rate Change

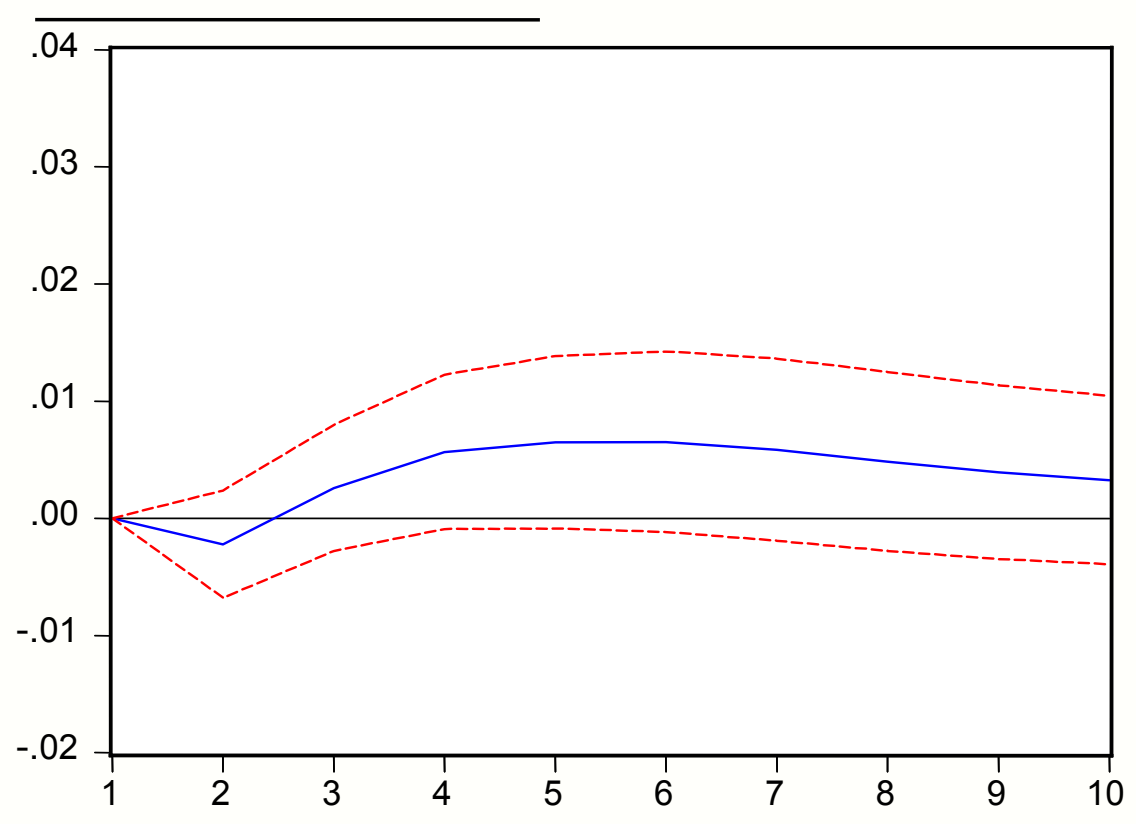

Source: Authors' calculations.

\section{Constraints, Vulnerabilities, AND the RoAd Ahead}

\section{A. Background}

Recent research in Belarus has made notable contributions to understanding monetary policy transmission. ${ }^{15}$ The professional consensus appears to be that the credit channel, exchange rate channel, and interest rate channel are operational in Belarus (roughly in this order of importance). However, specific features of the Belarusian economy-notably the use of the exchange rate as a nominal anchor in recent years, limited capital flows, banks' relatively passive role in credit allocation and more generally, pervasive direct intervention by the authorities in the economy - strongly affect the strength and predictability of transmission. Specifically, Belarus's shallow and underdeveloped capital market and government pressure to lower interest rates limit the NBRB's capacity to use the interest rate channel of monetary transmission. ${ }^{16}$ Interestingly, the mirror image of monetary policy transmission - the NBRB's reaction function - appears not to be analyzed, and there is relatively little discussion of the expectations channel despite its importance in making the exchange rate anchoring strategy effective.

\footnotetext{
${ }^{15}$ See Kallaur and others (2005), Krivorotov (2005), Korchagin (2004), Kruk (2005), and references therein.

${ }^{16}$ Banks are able only to partly offset the administrative lowering of interest rates through higher commissions and fees, so the operation of the interest rate channel is undermined.
} 
Monetary policy implementation in recent years has benefited from favorable influences. Brisk real GDP growth and rapid credit expansion has been accompanied by declining inflation and interest rates, as well as stabilizing exchange rate expectations. These developments were supported by ongoing increases in the demand for rubels, a negative (albeit rapidly closing) output gap, fiscal prudence, and limited capital mobility. In these circumstances, the NBRB has managed to avoid exchange rate fluctuations so far despite low official foreign exchange reserves owing to favorable terms-of-trade developments, to centralized control over economic activity and foreign exchange demand, as well as to the availability of large enterprise-level credit lines from Russia.

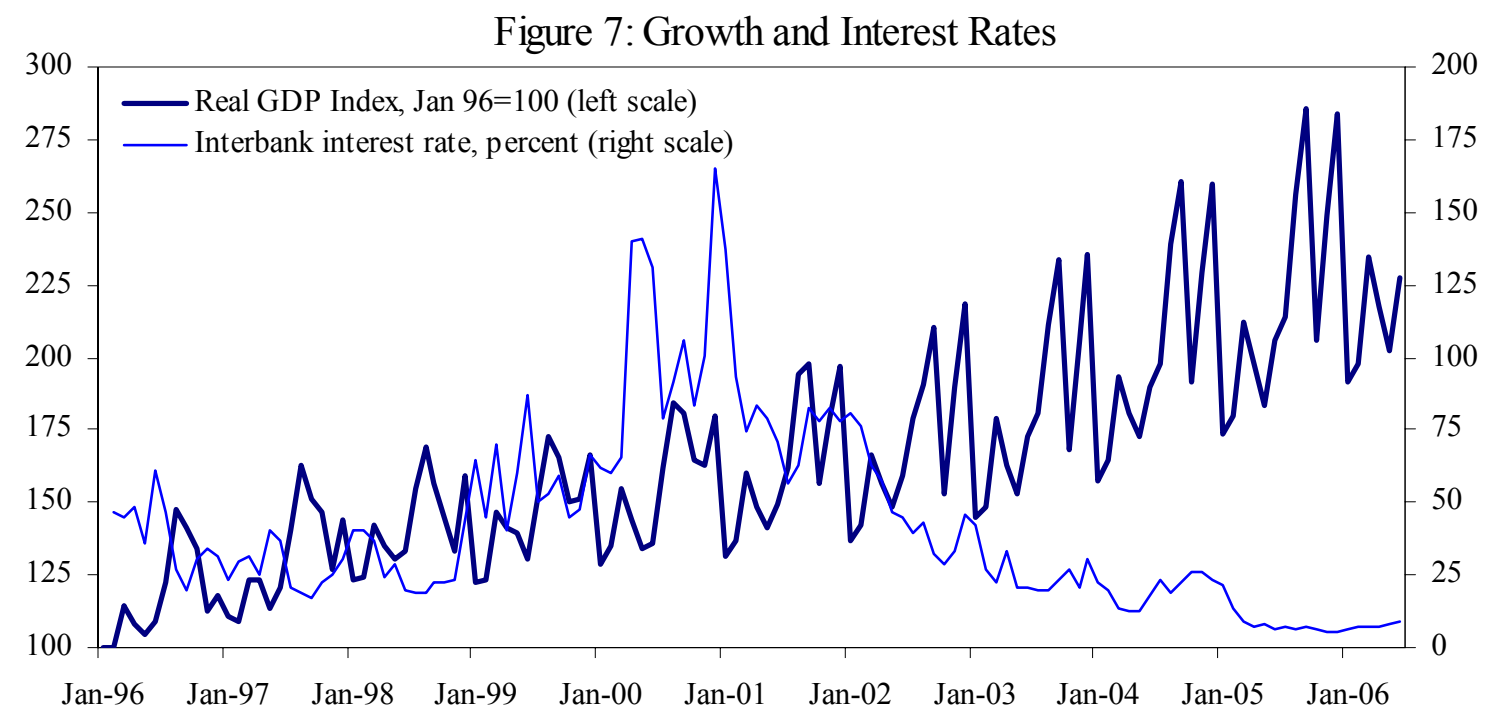

Source: National authorities; and IMF staff estimates.

However, the NBRB's monetary policy strategy faces serious risks. Large-scale directed credit has increased banking system fragility, which the placement of government deposits in large state-owned banks could only remedy temporarily. Dollarization, low foreign exchange reserves of the banking system, and the fragility of exchange rate and inflation expectations make the monetary policy framework vulnerable to exogenous shocks. In the period ahead, the economy may face risks stemming from the possibility of further real appreciation if prices and unit labor costs continue to rise faster than in partner countries, and of a consumption boom followed by a decline, typical for exchange rate-based stabilizations. ${ }^{17}$ With refined oil products based on Russian crude imported at below world market prices accounting for almost two-thirds of exports to the EU, the economy is also vulnerable to a reversal (or even discontinuation) of recent large terms-of-trade improvements. Finally, future shocks could emanate from policy decisions - such as the surge in reserve money growth in December 2005 and its subsequent return to trend.

${ }^{17}$ See for example, Kiguel and Liviatan (1992), and Hamann (2002). 
In addressing the risks, the NBRB faces various constraints that substantially limit its room for maneuver. Dollarization, the limited scope and effectiveness of monetary policy instruments, and institutional factors are among those that cannot be changed in the short run. Dollarization is likely to be a permanent feature of the financial landscape given entrenched expectations that deviations from macroeconomic stability would cause the Belarusian rubel to weaken. Consequently, exchange rate movements could trigger balance sheet effects that lead to household and enterprise losses.

Policy choices also constrain monetary policy implementation. In particular, the hierarchy of monetary policy objectives - on inflation, exchange rates, directed bank credits, bank recapitalization, the share of nonperforming loans, wages expressed in U.S. dollars, and direct support to nonfinancial enterprises - is vague. Furthermore, the de jure and de facto exchange rate targets do not coincide, eroding NBRB credibility. Officially, the authorities are targeting the Russian ruble, the currency of Belarus's largest foreign trade partner as well as foreign investor, while de facto the NBRB targets the U.S. dollar (Figure 8). Banking system foreign exchange reserves are precariously low, ruling out significant foreign exchange intervention to support the rubel. Finally, the NBRB's room for maneuver is restricted by its limited operational independence to pursue its inflation objective (evidenced, for example, by the rapid directed credit increase).

Figure 8: Monthly Exchange Rates

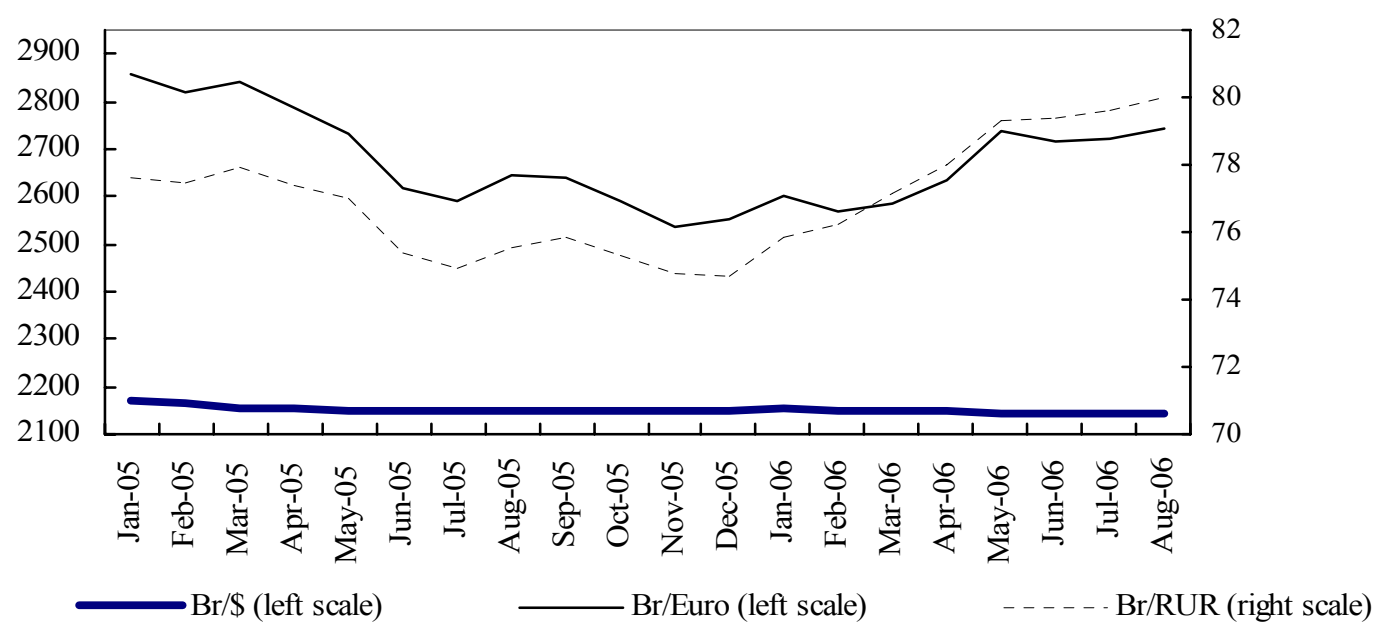

Source: National Bank of the Republic of Belarus 


\section{B. The NBRB's Reaction Function}

Against this background, we estimate a linear reaction function to changes in economic fundamentals for the NBRB, assuming the use of a crawling exchange rate band for guiding monetary policy. As noted above, central banks in general use short-term interest rates as the operating instrument to implement monetary policy. However, the interest rate channel has not been effective in Belarus in recent years and, at the same time, there was a desire to maintain the real exchange rate within a certain band. Hence, we assume that the monetary authority, given all the information available at time $t,\left(\Omega_{t}\right)$, adjusts its target for the change in the exchange rate $\left(\Delta e_{t}^{*}\right)$, while also responding to expected changes in inflation and output (the targeted change in the exchange rate was proxied in the calculations by the actual change). More specifically, and using the expectation operator $(E)$,

$$
\Delta e_{t}^{*}=\Delta \tilde{e}+a\left[E\left(\pi_{t+j} \mid \Omega_{t}\right)-\tilde{\pi}\right]+b\left[E\left(y_{t+h} \mid \Omega_{t}\right)-\tilde{y}\right]+\Delta F F_{t}
$$

where $\Delta \tilde{e}$ represents the change in the long-run equilibrium exchange rate; $\pi_{t+j}$ is the inflation rate in period $t+j ; \quad y_{t+h}$ is real production in period $t+h ; \tilde{\pi}$ and $\tilde{y}$ represent the targets for inflation and output, respectively; and $F F_{t}$ stands for foreign interest rates proxied by the U.S. Federal Funds Rate.

The estimated baseline reaction function assumes that the exchange rate is typically used to compensate deviations of inflation from implicit targets. ${ }^{18}$ In particular, the equation describes changes in the nominal exchange rate $e$ in reaction to (i) the gap between the current inflation rate and its target; (ii) a similar gap for output; (iii) the real exchange rate $(R E E R)$, to take into competitiveness considerations; and (iv) the U.S. Fed Fund rate $(F F)$, to account for interest rate parity. Thus, the specification is:

$$
\Delta e_{t}=\alpha+\beta \pi_{t}+\delta y_{t}+\phi \Delta R E E R_{t}+\kappa F F_{t}+\lambda \Delta e_{t-1}+\varepsilon_{t}
$$

The results for the period June 1996-October 2005 presented in Table 4 are based on the Generalized Method of Moments (GMM) technique, which provides better results in the presence of simultaneity and endogeneity. ${ }^{19}$

Table 2. Reaction Function (Based on GMM), 1996-2005

\begin{tabular}{cccccccc}
\hline$\alpha$ & $\pi_{\mathrm{t}}$ & $y_{t}$ & $\Delta R E E R_{t}$ & $F F_{t}$ & $\Delta e_{t-1}$ & $\mathrm{R}^{2}$ & $\begin{array}{c}\text { Durbin- } \\
\text { Watson }\end{array}$ \\
\hline-0.00 & 0.86 & -0.00 & -0.73 & 1.01 & 0.10 & 0.73 & 2.15 \\
$(-1.22)$ & $(3.11)$ & $(-0.71)$ & $(-4.10)$ & $(5.88)$ & $(0.85)$ & & \\
\hline
\end{tabular}

1/ T-statistics appear in parentheses. The optimal weighting matrix used in this estimation was obtained from a first step two-stage least squares parameter estimates. Instruments: lagged values of inflation, estimates of output gap, and changes in REER. A positive $\triangle$ REER corresponds to depreciation.

\footnotetext{
${ }^{18}$ Parrado (2004) explains the use of a trade weighted exchange rate index by the Monetary Authority of Singapore to offset fluctuations in both inflation and output.

${ }^{19}$ Following the methodology suggested by Clarida et al. (1998), policy reaction functions were first estimated on monthly data from 1995 to 2005 . The output deviation estimates relied on a Hodrick-Prescott filter.
} 
We have assumed a forward-looking horizon of one month. The coefficient associated with the inflation rate is positive and significant, suggesting that the NBRB exhibits a statistically significant accommodative exchange rate policy when the rate of inflation changes. In particular, the coefficient is less than one, indicating that a 1 percent increase in inflation is associated with an exchange rate depreciation of 0.86 percent. This behavior seems to strike a balance between attempting to preserve the external stability of the rubel, and pursuing a domestic inflation objective.

The coefficient associated with the output gap is insignificant and close to zero, consistent with the notion that the monetary authority was more concerned about stabilizing inflation than output. The coefficient associated with changes in the real exchange rate is significant and negative in sign, indicating that a real exchange rate depreciation led to a slower crawl. The coefficient that captures policy inertia $(0.10)$ is statistically insignificant, unlike the Fed Fund rate's positive coefficient. The latter suggests that interest rate parity was a binding constraint, i.e., the nominal exchange rate had to depreciate whenever the interest rate differential vis-à-vis domestic interest rates in Belarus increased.

The estimated reaction function is consistent with the hypothesis that an important concern of the NBRB was to control inflation. Nevertheless, concerns about the real exchange rate also appear to have played a role, consistent with a desire to safeguard competitiveness. The forward-looking nature of monetary policy seems to be based on a short-term forecast (the estimates suggest that the coefficient for inflation is significant for a one-month target horizon). To enhance the forward-looking nature of monetary policy, the central bank will need to improve its inflation forecast and extend its horizon.

To assess the fit and historical accuracy of the estimated reaction function, Figure 9 exhibits the estimated changes in the nominal exchange rate based on equation 2 against the actual changes from 1996 to 2005. The minimal residual implies a close tracking, suggesting that the model provides a reasonable explanation of Belarusian exchange rate policy in the sample period. The residual is large only during and immediately after the Russian crisis. Interestingly, monetary policy appears to have been tighter in the first part of 1998 than the projections implied by the rule, and somewhat looser at the beginning of 1999. 
Figure 9. Changes in the Nominal Exchange Rate, 1996-2005

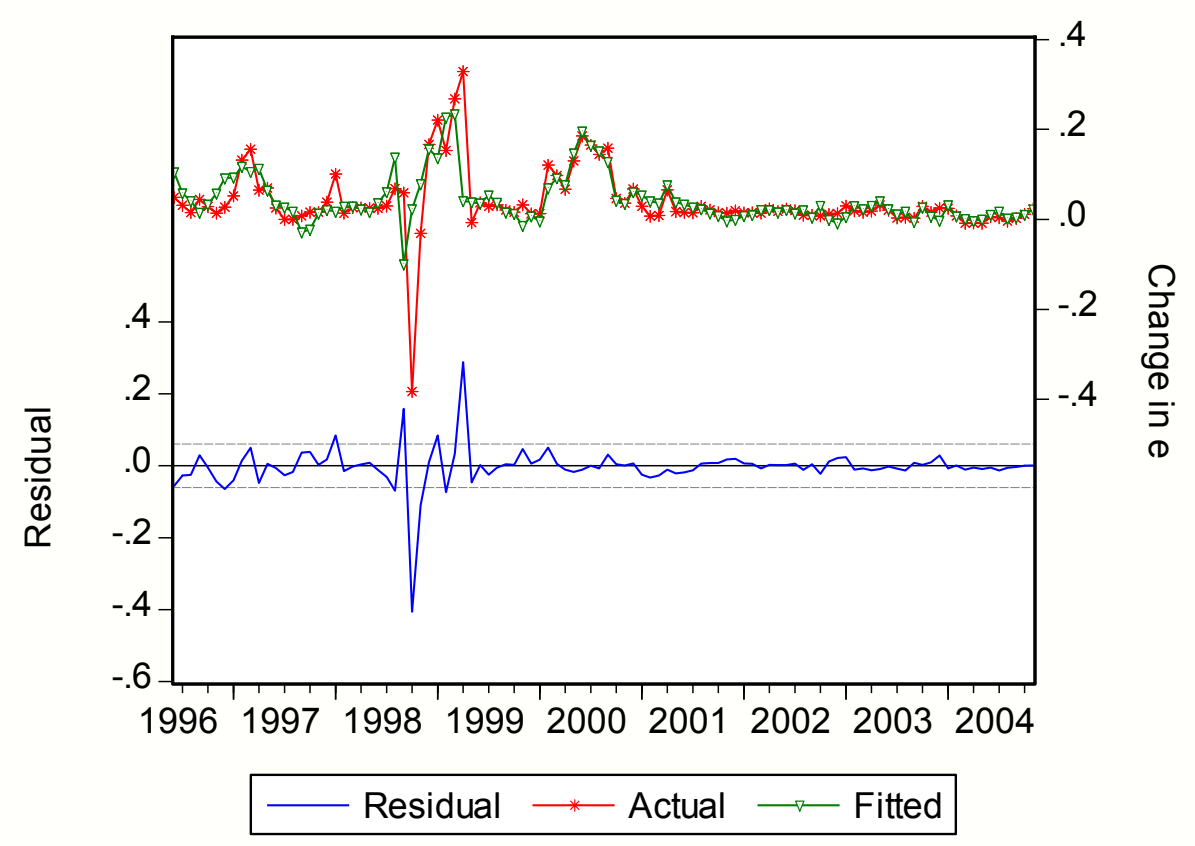

Source: Authors' estimates

\section{Steps Toward Enhancing Monetary Policy Effectiveness}

While the empirical results point to some strengths in monetary policy, considerable room for improvement remains. Monetary policy effectiveness would benefit from a more transparent framework including a clear hierarchy of monetary policy targets with inflation as the primary target, from strengthened NBRB policy autonomy, and from supportive fiscal and quasi-fiscal policy. In this regard, the divergence between the central bank's de jure and de facto exchange rate objectives remains an obstacle for transparent monetary policy implementation. The NBRB could more effectively pursue low inflation if it was freed from policy constraints imposed by the plethora of existing quantitative targets, notably on the nominal exchange rate, on directed credits, on interest rates, and on economy-wide wage increases. Timely information flow and policy coordination with fiscal authorities would also help support effective monetary management.

The NBRB would also benefit from the enhanced operation of monetary policy transmission channels. In particular, interest rates could play a more substantive role if financial markets deepened, interest rate control was abolished, and bank privatization proceeded. However, interest rate policy will face challenges. With the possible rise in inflationary pressures, the NBRB might find expectations less firmly anchored than currently thought, perhaps requiring interest rate hikes. On the other hand, weakening domestic demand-and other possible shocks, for example, a growth slowdown in key partner countries or worsening terms of trade - may limit the desirability of higher interest rates. Meanwhile, if foreign interest rates rise, Belarus will need to maintain positive interest rate differentials despite some cushioning 
provided by limited capital mobility. The level of the real exchange rate and the current account deficit requiring financing would also affect the choice of the interest rate level.

Support from other policy areas would be key for attaining a transparent hierarchy of policy objectives with a clear primacy for the inflation target. Clearly, the main instrument for handling real exchange rate pressures would be fiscal and quasi-fiscal prudence. The NBRB alone cannot prevent changes in the real exchange rate. It can ensure, however, that this does not occur through swings in the price level that may unanchor inflation expectations and trigger further administrative price intervention or capital flight.

The key criterion for selecting intermediate monetary policy targets is a stable relationship with inflation. The level of intermediate targets should influence broader monetary aggregates - such as credit to the private sector - as well as expectations. For example, shifts in M1 affect interest rates and the availability of funds in the money market, influencing aggregate demand and inflation over time. Thus, the NBRB could calibrate changes in M1, short-term interest rates, and the exchange rate as intermediate targets to guide expectations and the long end of the yield curve. These are critical for managing households' and firms' decisions on spending, as well as for inflation, the final goal of monetary policy.

Banking system resilience is critically important. A well-capitalized, profit-oriented banking system would create a natural buffer against exogenous shocks and balance sheet risks. However, systemically important state-owned banks in Belarus today act mainly as conduits for large-scale directed lending to priority sectors - often on preferential terms. They have a high sectoral lending concentration, and their lending rates are subject to administrative restrictions affecting their ability to adequately price risk, especially on longer-term lending. As a result, overall banking sector profitability is low and the sustained rapid loan growth of recent years raises concern about future increases in nonperforming loans. Moreover, large state-owned banks need to rely on recurrent large-scale government support to underpin their liquidity and capital positions.

Structural reforms aimed at financial deepening and reducing the current predominance of state ownership of banks could usefully complement improvements in the NBRB's capacity to effectively implement monetary policy. At present, large-scale intervention in credit allocation and the systemically important state-owned banks' lack of pursuit of the profit motive introduce distortions to financial intermediation that critically weaken monetary policy transmission channels. Structural reforms in the financial sector could be along the lines envisaged in the NBRB's Concept of Banking System Development, complemented by bank privatization. The resulting improvements in the responsiveness of banks to changes in business conditions and their heightened autonomy in allocating credit would greatly raise monetary policy effectiveness. 


\section{REFERENCES}

Allen, Mark, and others, 2002, "A Balance Sheet Approach to Financial Crisis," IMF Working Paper 02/210 (Washington: International Monetary Fund).

Bernanke, Ben S., Mark Gertler, 1995, "Inside the Black Box: The Credit Channel of Monetary Policy Transmission,” NBER Working Paper No. 5146, p. 47 (Cambridge, Massachusetts: National Bureau of Economic Research).

Calvo, G.A., 1999, Fixed Versus Flexible Exchange Rates: Preliminaries of a Turn-ofMillennium Rematch, (University of Maryland) unpublished; College Park.

Cespedes, L.F., R. Chang, and A. Velasco, 2000, "Balance Sheets and Exchange Rate Policy,” NBER Working Paper No. 7840 (Cambridge, Massachusetts: National Bureau of Economic Research).

Eichengreen, B, and R. Hausmann, 1999, "Exchange Rates and Financial Fragility," paper presented at the Federal Reserve Bank of Kansas City conference on Issues in Monetary Policy, Jackson Hole, Wyoming, August 27-29.

Égert, Balázs, and Ronald McDonald, 2006, "Monetary Policy Transmission Mechanism in Transition Economies: Surveying the Surveyable," Working Paper No. 1739 (Munich: CESifo).

Hamann, J., 20001, "Exchange-Rate-Based Stabilization: A Critical Look at the Stylized Facts," Staff Papers, IMF, Vol. 48, No. 1, pp. 111-38.

Ize, A., and E. Levy Yeyati (2003) "Financial Dollarization," Journal of International Economics, Vol. 59, No. 2, pp. 323-47.

Kallaur P.V., Komkov V.N., Chernookii V.A., 2005, “A Transmission Mechanism of the Monetary Policy in Economy of the Republic of Belarus," Belarus Economic Journal, No. 3.

Korchagin, Oleg, 2004, "Models of Monetary Policy Transmission Mechanisms," Bank Bulletin Magazine (Bankovski Vestnik) of the NBRB, No. 14 (288), (September) pp. 40-44. Available in Russian at http://www.nbrb.by/bv/narch/288/9.pdf.

Kiguel, M., and N. Liviatan, 1992, "The Business Cycle Associated with Exchange RateBased Stabilizations," The World Bank Review, Vol. 6, No. 2 pp. 279-305.

Krivorotov, D.V., 2005, “The Transmission Mechanism of Monetary Policy” Minsk: Research Center of the Institute for Privatization and Management.

Kruk, D., 2005, "Problems of Identifying Transmission Mechanisms in Belarus," Minsk: Research Center of the Institute for Privatization and Management.

Loayza, Norman, and Klaus Schmidt-Hebbel, 2002, "Monetary Policy: Rules and Transmission Mechanisms" Santiago: Banco Central de Chile. 
Mishkin, Frederic S., 1995, "Symposium on the Monetary Transmission Mechanism," Journal of Economic Perspectives, Vol. 9 (Fall), pp. 3-10.

Modigliani, F., 1975, "The Life Cycle Hypothesis of Saving Twenty Years Later," Contemporary Issues in Economics, ed. M. Parkin (Manchester: Manchester University Press).

Parrado, Eric, 2004, “Singapore’s Unique Monetary Policy: How Does it Work?” IMF Working Paper 04/10 (Washington: International Monetary Fund).

Pelipas, Igor, 2002, "Money and Prices in Belarus: Information Content of Different Monetary Aggregates" Minsk: Research Center of the Institute for Privatization and Management.

Rudiy, Kirill, 2003, "Monetary Policy Transmission Mechanism,” Bank Bulletin Magazine (Bankovski Vestnik) of the NBRB, No. 13 (234), (May) pp. 30-34.

Savastano, Miguel, 1996, "Dollarization in Latin America: Recent Evidence and Some Policy Issues,” IMF Working Paper 94/4 (Washington: International Monetary Fund).

Starr, Martha A., 2005, "Does Money Matter in the CIS? Effects of Monetary Policy on Output and Prices," Journal of Comparative Economics, Vol. 33, pp. 441-61.

Taylor, Mark P., and Michael J. Artis, 1993, "The Stabilizing Effect of the ERM on Exchange Rates and Interest Rates: An Empirical Investigation," IMF Working Paper 93/67 (Washington: International Monetary Fund). 